\title{
On Financial Management for SMEs under New Conditions
}

\author{
Li He \\ School of Accounting, Shandong Economic University \\ Jinan 250014, China \\ E-mail: helizh@163.com
}

\begin{abstract}
The financial crisis erupted in 2008 makes the current global economy remain uncertain. SMEs, as an important force in China's national economy, face a crisis of survival due to the more difficult business development. An important reason is that SMEs overlook the central position of financial management, so that the role of financial management has not been fully realized. In order to minimize the loss of SMEs to enhance their ability to withstand the crisis and master a rare strategic opportunity, to strengthen the financial management is very important.
\end{abstract}

Keywords: Economic crisis, SMEs (Small and medium-sized enterprises), Financial management

Since the reform and opening up, China's SMEs develop with energy, playing an important role in economic growth and social stability. In 2008, the financial crisis triggered by the U.S. subprime mortgage crisis makes global economy enter the cold. Chinese enterprises, especially SMEs, suffer a lot. Only in the first half of 2008, more than 60,000 SMEs were bankrupted, merged, or purchased. Till the first half of 2010, many economic indexes have improved in China. But under the common context of global economic integration, the future is still uncertain. SMEs still face severe challenges. Compared with large enterprises, China's SMEs can not resist crisis risks properly. An important reason is the difference in financial management. Financial management is the core of an enterprise's whole management system. Enterprises with standard financial management and perfect system are more flexible in crisis resistance and fine management. In front of new situation, SMEs should be actively self-adjustment, especially in the financial management, reforming boldly to adapting to environment changes.

\section{SMEs' financing issue}

Since the reform and opening up, China's SMEs are always at a fast growing stage. However, difficult financing is a bottleneck limiting the fast development of SMEs. Under the overwhelming economic crisis, this problem tends to be more prominent.

\subsection{SMEs' financing conditions}

Today China sets up many hard regulations on enterprises issuing stocks and securities. Many SMEs can not reach relevant standards. So, for SMEs, the main financing way is the accumulation of their own profits. In external financing, they rely on debt financing heavily, especially on bank loans. However, because of SMEs' small size, loose internal control, and poor transparency, it is hard for them winning the trust of banks. Loans from banks can not satisfy SMEs' needs. After the outbreak of economic crisis, the market downturns and the sales are down. But money are not paid in time and prices of raw materials and labor forces are rising, which makes many SMEs' money flow stop. Meanwhile, due to the rise of uncertainty, banks are more careful in lending money to SMEs and set up stricter evaluation mechanism in order to avoid risks.

\subsection{Measures for solving the difficult financing of SMEs}

On one hand, SMEs must establish a sound financial system and institutional setting, and compose financial statements by strictly following accounting principles, in order to maintain the accounting materials' authenticity, integrity, and credibility. In business process, adopt the centralized account management mode as far as possible, enhance an unified cash management awareness, establish a good credit image, creating a nice condition for successful financing. On the other hand, SMEs should actively broader the financing channels. For internal financing, SMEs can dig out their own potentials, emphasize on capital accumulation, and gradually increase the proportion of own funds. Listed SMEs can divide the net assets into shares and raise funds by managerial ownership, employee ownership, and certain shareholders rationing, realizing the diversification of shares in order to alleviate the financial pressure in economic crisis. For external financing, firstly SMEs should foster good financial and cooperative relationships with banks, and investors, actively exchanging ideas with them concerning corporate management policy, development plans, and financial conditions. Secondly, if individual loans are difficult, SMEs can combine together to form a mutual aid organization, absorbing social funds, or 
organize to form a joint guarantor, member enterprises taking joint liabilities, reducing banks' risks. Finally, under the influences of present economic risks, SMEs can solve the financing issues and step out of the haze of economic crisis by non-traditional financing ways, such as financial leasing, bank discount, and pawn.

\section{Problems in SMEs investment}

In order to sustain production or win development, SMEs may face many investment opportunities in business management. They must make right decisions.

\subsection{Present conditions of SMEs investment}

In China, SMEs do not form a perfect management mechanism and the investment decision-making is mostly in the hands of business owners, which makes the investment process lack of internal restrains. The market research is not deep. Then, SMEs can not exactly grasp the market needs. Under the impact of financial crisis, two different investment trends appear in SMEs. For the first trend, affected by the crisis, facing an unoptimistic situation, enterprises are forced to cut or suspend production, reducing investments substantially, or even bankruptcy, to avoid risks. For the second trend, affected by the crisis, under the condition of few competitors and more state policy support, enterprises speed up technological innovation, equipment update, and new production development, increasing more investments. However, some enterprises blindly follow the trend, not make necessary investment feasibility analysis, which causes low rate of investment return. The investment does not achieve the expected result.

\subsection{Measures for solving the difficult financing of SMEs}

Firstly, SMEs should carefully choose the investment strategy, focusing on inward investment. Facing the economic crisis, Chinese government takes these measures: stabilizing, recovering, and increasing exports, encouraging consumption, and expanding domestic needs. In early 2010, China advances the policy for transforming business mode, and adjusting economic structure. Therefore, SMEs should focus on benefiting production exports and expanding domestic needs. Facing market needs, SEMs must make market analysis. On one hand, strengthen the investment project's feasibility research and demonstration and optimize the investment program. On the other hand, strengthen the investment project's evaluation and review and strive to improve the investment return. Enterprises should adjust product structure and perform integration based on market demand, get rid of business without efficiency and competitiveness, maintain and improve the core business, and highlight the core competitiveness.

Secondly, SMEs should set up rules for the choice of investment, the applied research, the evaluation of products and decision-making, and the execution of investment, and carry them out strictly. Establish a system for investment plans' composition, approval, and financial analysis, standardizing investment process. Summarize successful experiences for project investment. Implement the investment supervision, and enhance the project control and management in practice. Meanwhile, be aware of every stage of the investment project. Pay attention to the progress of each project. Make adjustment in time. Guarantee a precise state of the project from design to implementation.

\section{Other financial management issues for SMEs}

Considering present critical situation, SMEs have to address several important issues to comprehensively strengthen the financial management level and improve the ability to defuse the crisis.

\subsection{The financial management mode}

Modern enterprise is based on the separation of ownership. However, most SMEs are private. The typical management mode is still the high unity of ownership and management. This mode is bound to bring more negative business impacts on enterprises' financial management. For example, the phenomena of enterprise owners' centralized and family management are serious. Managers are short of business decision-making right. The recognition and application of modern financial management ideas and methods are insufficient. The management ideas are out of date. All these factors make the financial management lost its rightful place and role in business management.

Under the background of financial crisis, in order to change the unfavorable situation, SMEs need to abandon the family management mode, improve the overall quality of management, fully dig out financial talents, actively absorb and employ excellent talents. Establish a decision-making body composing of experts, technologists, managers, and employee representatives, and make the decision- making objective, scientific, and feasible. Reduce errors as far as possible, and improve the efficiency constantly.

\subsection{Cost control}

In cost control, SMEs are in the subsequent accounting period. Policies for fixed standards and information 
feedback are imperfect. And the advance control and the process control are poor. The spread of economic crisis and the shrink of market demand cause the decline of sales. Enterprise costs tend to be rigid. Meanwhile, enterprises do not pay attention to the accumulation of retained earnings in distributing profits. As a result, enterprises have no sufficient funds for further development.

To control the cost strictly is an important measure for enterprises dealing with the impacts of world financial crisis. SMEs should establish a consciousness of conservation and reduce unnecessary expenditure considering self conditions. By strengthening an overall budget management, enterprises can identify the main contents of cost control, master the controllable costs, analyze the cost factors, make the scientific budget, and develop out a practical cost control index. To ensure the realization of cost control targets, enterprises can target down to every level, implement a clear responsibility for cost management, and carry out the cost control policy properly.

\subsection{Cash management}

Chinese SMEs pay more attention to profits rather than cash flow in daily evaluation. Most SMEs neglect of cash flow management, lacking of a scientific recognition to cash management. Some enterprises neglect the costs of using cash and agree that the more cash, the better, which leads to unused funds and low rate of using funds. Some enterprises do not make plans for using funds. They purchase too much real estate and inventory. As a result, these enterprises may face financial problems due to the lack of cashes.

In order to deal with economic crisis and ensure enterprises' normal operation and long-term development, sufficient cash flow is essential. SMEs should establish a financial management idea focusing on cash management, strengthen the management of budget's composition, implementation, analysis, and evaluation, specify cash budget project and build budget standards, regulate the process of budget composition, examination, approval, and execution. By this way, enterprises can control the cash flow, guaranteeing the needs for production and the maximum profits. Besides, enterprises should strengthen the daily management of accounts receivable and prepayment, comprehensively understand the customers' abilities to repay debts and credit conditions, make up a scientific and reasonable debt collection policy, accelerate the recovery of investments, and reduce bad debts.

\subsection{Defend financial risks}

In front of the economic crisis, Chinese SMEs can not resist risks powerfully. The reason is that enterprises can not plan ahead, no perfect risk-control system and financial early warning mechanism. In decision-making, enterprises do not consider financial crisis fully, causing an unbalanced capital structure and high business risks. Enterprises can not make sufficient analysis of financial information, and do not build a financial risk defend system due to a failure of finding main reasons for some errors. Finally, enterprises can not connect certain risk responsibility with specific department or individual.

In the current situation, SMEs should pay more attention than ever to the prediction and analysis of financial risks. On one hand, establish a correct attitude to financial risk management, adhere to the prudent financial risk management concept, evaluate and deal with risks more comprehensively, and get rid of lucky views. On the other hand, strengthen the risk management task. Build a risk early warning system, which can help to detect risks in advance. Improve the emergency response mechanism and ensure the survival of enterprises.

In summary, SMEs should deal with present economic crisis properly, finding potential opportunities from crisis. Make best use of all official support policies and resources. Expand financing channels. Regulate the investment decision-making. Explore the new mode of financial management actively. Establish the modern financial management idea. Meanwhile, strengthen the financial accounting, cost control, and cash flow management. Improve the consciousness of risks. Keep in improving financial management level. Then, enterprises can strengthen their core competence and win its place in market.

\section{References}

Gao, Hai. (2009). SMEs financial management strategy in financial crisis. Money China. No.10.

Huang, Bin. (2009). On financial management issues in SMEs and countermeasures. Economic Research Guide. No.25.

Li, Yining. (2007). On Private Economy. Beijing: Beijing University Press.

Xiong, Ya. (2010). Research on SMEs financing issues in financial crisis. Enterprise Economy. No.1. 